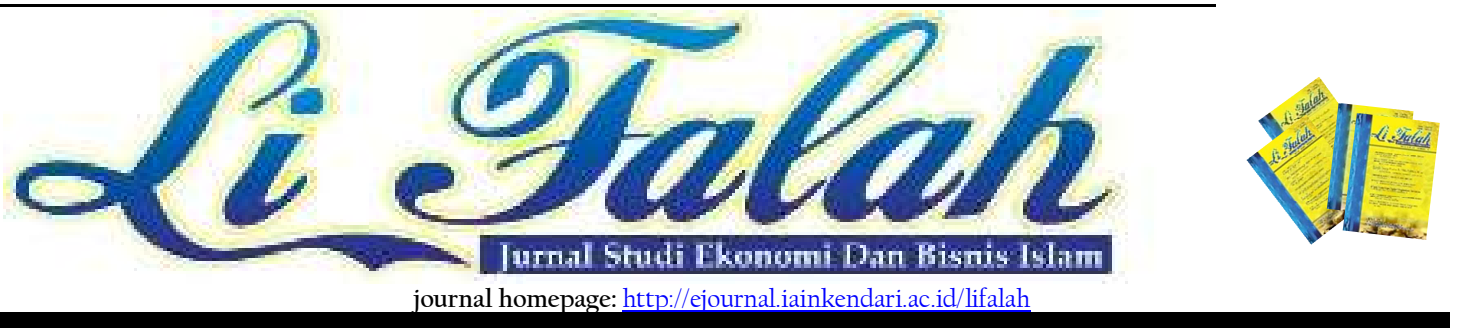

\title{
Analisis Implementasi Prinsip Bisnis Ala Rasullulah Oleh Groceries Stall Di Pasar Sentral Kota Kendari
}

\author{
Adzil Arsyi Sabana', Ummi Kalsum², Muhammad Imran ${ }^{3}$, Kiki Novita Sari ${ }^{4}$, Dewi \\ Santri ${ }^{5}$
}

${ }^{1}$ Fakultas Ekonomi dan Bisnis Islam IAIN Kendari Email: adzilrantas@gmail.com

${ }^{2}$ Fakultas Ekonomi dan Bisnis Islam IAIN Kendari Email: kalsumummi75@gmail.com

${ }^{3}$ Fakultas Ekonomi dan Bisnis Islam IAIN Kendari Email: muhimran@iainkendari.ac.id

${ }^{4}$ Fakultas Ekonomi dan Bisnis Islam IAIN Kendari

Email: kikinovitakendari@gmail.com

${ }^{5}$ Fakultas Ekonomi dan Bisnis Islam IAIN Kendari

Email: dewisantri@iainkendari.ac.id

\section{INFO ARTIKEL}

\section{Keywords:Implementasi}

prinsip Bisnis Islam,

Groceries stall

DOI:

http://dx.doi.org/10.31332/lifalah.v5il.1959
A B S T R A K

Penelitian ini dilaksanakan di pasar sentral Kota Kendari, dengan obyek penelitian groceries stall yang melakukan aktivitas berdagang di pasar sentral Kota Kendari, adapun tujuan penelitian ini adalah untuk menganalisis sejauh mana penerapan prinsip bisnis islam yang dilakukan groceries stall di pasar sentral Kota Kendari dengan menggunakan sampel sebnyak 21 responden dari 38 groceries stall yang di tentukan dengan sensus dan menggunakan analisis deskriptif kualitatif dengan mengguanakan alat nalisis tabulasi silang. Data primer diperoleh melalui wawancara kepada responden dan dan data skunder darikantor Walikota Kendari. Ruang lingkup penelitian ini adalah implementasi prisip bisnis islam ala Rasulullah. Berdasarka hasil penelitian dan analisis menunjukan bahwa rata-rata 88,12\% groceries stall di pasar sentral Kota Kendari telah menerapkan kelima prinsip bisnis Islam ala Rasulullah, yakni (l) mancapai kepuasan dan keuntungan secara halal; (2) Jujur dan transparan; (3) memperlakukan tenaga kerja sebagai mitra; (4) menghindari sistim Ribawi. Responden dengan persentase tertinggi adalah 100\% yakni memperlakukan tenaga kerja sebagai mitra, sedangkan responden dengan persentase terendah adalah 80,5\% jujur dan transparan dalam berniaga. 


\section{Pendahuluan}

Dalam suatu perekonomian yang berorientasi untuk saling melengkapi dalam tatanan kehidupan sehari-hari tidak dapat dipisahkan aktifitas ekonomi dimana interaksi antara produsen dan konsumen untuk mengarahkan manusia kearah lebih sejaterah dalam kehidupan.

Islam telah mengatur bahwa interaksi ekonomi dalam suatu bisnis atau perdagangan tidak dapat mengabaikan dari nilai-nilai dasar yang tekandung dan di tetapkan dalam al-Quran dan Hadis serta referensi-referensi hukum Islam lainya, seperti halnya ekonomi konvensional yang mengatur bagaimana mengatur pendapatan dan pengeluaran yang bersifat material dan non material dalam hal memenuhi kebutuhan manusia.

Masyarakat dunia masih memiliki fanatisme terhadap sistem bisnis konvensional, termasuk umat islam yang masih mempraktekkan teori bisnis dalam kegiatan usahanya, hal ini mengakibatkan suatu paradigma bahwa ilmu islam hanya sekedar catatan historis saja, yang tidak pernah di praktekkan dalam kehidupan modern, bahkan oleh Negara-Negara yang mayoritas muslim (Maulana, 2013)

Agama islam menetapkan jual beli sebagai tolak ukur kejujuran, kepecayaan dan ketulusan. Baik penjual maupun pembeli keduanya harus menerapkan nilainilai kejujuran. Tidak menipu, memaksa berbuat curang dan lain sebagainya. Dewasa ini banyak ketidak sempurnaan pasar yang jauh dari prinsip-prinsip perdagangan, dimana prinsip perdagan ini telah ada dalam Al-qur'an dan hadist, seperti memberikan takaran yang tidak benar, Padahal bermain curang seperti ini terancam dalam Al-Qur'an:

"kecelakaan besarlah bagi orang-orang yang curang, (yaitu) orang-orangyang apabila menerima takaran dari orang lain mereka meminta dipenuhi, dan apabila mereka menakar atau menimbang untuk orang lain mereka mengurangi. Tidaklah orang-orang itu menyangka, bahwa sesungguhnya mereka akan dibangkitkan pada suatu hari yang besar." (QS. Al muthoffifin: 1-3)

Terjadinya hal semacam ini dapat menyebapkan tujuan utama jual beli menjadi tidak tercapai. Sedangkan manusia pastinya mengiginkan perdaganggan yang sehat dan tidak merugi. Selain dalam perintah agama, Indonesia juga menerapkan prinsipprinsip bisnis, dimana bagi groceries stall terdapat dalam pasal 7 yakni beritikad baik, berprilaku jujur dan melayani konsumen dengan benar. Kemudian disusul dengan UU. No tahun 1999 yang menjelaskan tentang perlinndungan konsumen yang berasaskan hak atas kenyamanan, keamanan dan keselamatan dalam mengkonsumsi barang atau jasa. 
Namun dalam kegiatannya, masih di dapati adanya prilaku yang menyimpang yang dilakukuan oleh beberapa pedagang. Berdasarkan pengamatan penulis, beberapa pedagang ada yang memang sengaja tidak jujur untuk mengambil keuntungan lebih.

Di kota kendari khususnya, tidak sedikit yang mengeluti dunia kewirausahaan, salah satunya adalah groceries stall, mengigat kebutuhan atas sembako selalu mengalami peningkatan setiap priode. Akan tetapi masih ada beberapa pedagang yang tidak jujur dalam melakukan transaksi jual beli, karena berdasarkan pengamatan dan hasil observasi peneliti, bahwa ada beberapa keluhan dari masyarakat tentang kecurangan atau ketidak jujuran dalam transaksi jual beli penjualan sembako.

Sejumlah studi yang berkaitan dengan pedagang juga telah dilakukan, salah satunya dilakukan oleh martin (2019) yang menyatakan bahwa para pedagan di pasar baruga kendari belum seutuhnya menerapkan etika bisnis yang berdasarkan hukum Islam. Meski ada beberapa pedagan yang konsisten dengan Etika bisnis yang Islami.

Pada observasi awal di pasar sentral Kota Kendari peneliti sedikitnya telah di peroleh informasi tentang situasi perdaganan yaitu terdapat adanya keluhan dar beberapa konsumen yang menyatakan bahwa adanya prilaku pedagang yang tidak jujur dalam melakukan transaksi jual beli. Baik itu dalam hal takaran maupun timbangan. Inilah yang menjadi alasan utama peneliti sehingga memilih pedagan sembako sebagai objek penelitian.

Berdasarkan uraian latar belakang diatas, penelitian ini bertujuan untuk mengetahui sejauh mana penerapan prinsip bisnis islam yang dilakukan groceries stall di pasar sentral kota kendari.

\section{Tinjauan Pustaka}

\subsection{Bisnis dalam Pandangan Islam}

Menurut Ismail (2002), bisnis dapat dipahami sebagai serangkaian aktifitas bisnis dalam berbagai bentuknya yang tidak dibatasi jumlah (kuantitas) kepemilikan hartanya (barang/jasa) termasuk profitnya, namun dibatasi dalam cara porelehan dan pendayagunaan hartanya (ada aturan halal dan haram)

Bisnis merupakan salah satu hal yang amat penting dalam kehidupan manusia. Tidak heran jika Islam yang bersumber pada Al-Qur'an dann sunnah Nabi memberi tuntunan menyeluruh sekaligus petunjuk;petunjuknya berkaitan interaksi dalam bidang usaha dagang. Rasulullah yang di utus oleh Allah sebagai penyempurna ahlak juga memberi tuntunan yang berkaitan dengan bisnis, lebih-lebih bahwa Rasulullah sendiri pada 
masa mudanya adalah seorang pelaku bisnis suses (Haris, t.t.)

Melihat dari segi normative banyak sekali dalil dari Al-Qur'an maupun hadis yang menganjurkan menjadi seorang pebisnis. Dalam Al-Qur'an Allah berfirman

"Apabila telah di tunaikan shalat, maka bertebaranlah kamu di muka bumi; dan carilah karunia Allah dan ingatlah banyak-banyak supaya kamu beruntung." (2S. Al-Jumu'ah; 10)

Ayat ini menjelaskan adanya perintah untuk bertebaran dimuka bumi untuk mencari karunia Allah, maksudnya adalah anjuran berbisnis bagi umat muslim.

Beberapa hadis Rasulullah juga menganjurkan untuk menjadi groceries stall atau pebisnis seperti salah satu hadis yang berbunyi:

"Tidak ada satupun makanan yang lebih baik dari pada yang dimakanan yang dihasilkan dari keringat sendiri." (HR. Bukhari)

\subsection{Praktek Bisnis Nabi Muhammad} SAW.

Keberhasilan Rasulullah dalam mengelola bisnis di pengaruhi oleh kepribadian faktor kepribadian diri pribadi atas dasar dialogis realitas sosial masyarakat jahiliyyah dengan dirinya. Nabi Muhammad dalam berbisnis sangat banyak memberikan petunjuk mengenai etika bisnis diantaranya ialah (Muhammad saifullah, dalam jurnal etika bisnis islami dalam praktek bisnis Rasulullah,2003):

\subsubsection{Kejujuran.}

Nabi Muhammad dalam menjalankan transaksi bisnisnya menggunakan kejujuran sebagai etika dasar. Gelar al-Amin (dapat dipercaya) yang diberikan masyarakat Mekkah berdasarkan prilaku Muhammad sebelum menjadi pelaku bisnis. Belia berbuat jujur dalam segala hal, termasuk menjual barang dagangannya. Cakupan jujur ini sangat luas, seperti tidak melakukan penipuan, tidak menyembunyikan cacat pada barang dagangannya, menimbang barang dengan timbangan yang tepat, dan lain-lain. Dalam hal ini, belia bersabda:

"Tidak dibenarkan seorang muslim menjual suatu jualan yang mempunyai aib, kecuali ia menjelaskan aibnya." (H.R. Al-Quzwani). Siapa yang menipu kami, maka dia bukan kelompok kami.”(H.R. Muslim)

\subsubsection{Amanah.}

Berdasarkan konteks Fiqh, amanah memiliki arti kepercayaan yang di berikan kepada seseorang berkaitan dengan harta benda. Muhammad dalam berniaga menggunakan etika ini sebagai prinsip dalam menjalankan aktifitasnya. Ketika Muhammad sebagai salah satu karyawan Khadijah, ia memperoleh kepercayaan penuh membawa barang-barang dengan Khadijah untuk dibawa dan dijual di Syam. Ia menjaga barang dagangannya dengan 
baik selama dalam perjalanan. Dengan ditemani Maisarah, Muhammad menjual barang-barang tersebut sesuai amanat yang ia terima dari Khadijah.

Barang-barang dagangan tersebut habis terjual dan Tanpa diduga keuntungan Muhammad sangatlah besar dan membuat Khadijah puas. Hasil keuntungan tersebut ia laporkan dan serahkan kepada Maisarah tanpa kurang sedikitpun. Setelah itu Muhammad diberi upah sesuai dengan perjanjiannya, yakni empat kali dari gaji yang biasanya Khadijah berikan kepada karyawan lainnya.

\subsubsection{Tepat Menimbang.}

Etika bisnis Muhammad dalam menjual barang harus seimbang. Barang yang kering bisa ditukar dengan barang yang kering. Penukaran barang kering tidak boleh dengan barang yang basah. Demikian juga dalam penimbangan tersebut seseorang tidak boleh mengurangi timbang. Dalam transaksi. Muhammad menjauhi apa yang disebut dengan Muzabana dan Muhaqala. Muzabana Adalah Menjual kurma atau anggur segar (basah) Dengan kurma atau anggur kering Dengan cara menimbang. Muzabana pada dasarnya adalah Menjual sesuatu yang jumlahnya, Berat atau ukurannya diketahui dengan jelas. Muhaqala Adalah jual beli atau penukaran antara gandum Belum dipanen dengan gandum yang sudah digiling atau menyewakan tanah Untuk ditukar dengan gandum.

Muhammad menimbang berat sesuai dengan ukurannya. Iya tidak mengurangi sedikitpun, Sehingga Kejujuran dan ketepatannya dalam menimbang sudah tersebar di mana-mana.

\subsubsection{Gharar}

Gharar adalah akad yang mengandung unsur penipuan karena tidak adanya kepastian, baik mengenai ada atau tidak adanya objek akad, besar kecilnya jumlah, maupun kemampuan menyerahkan objek yang disebutkan dalam akan tersebut. Dalam praktiknya Muhammad menjauhi praktek gharar, Karena membuka ruang perselisihan antara penjual dan pembeli. Muhammad melarang penjualan dengan lebih dahulu memberikan uang muka atau panjar dan uang itu hilang jika pembelian dibatalkan.

\subsubsection{Tidak Melakukan Penimbunan Barang.}

Menurut istilah Arab penimbunan barang disebut ihtikar. Penimbunan ini tidak diperbolehkan karena akan menimbulkan kemudharatan bagi masyarakat karena barang yang dibutuhkan tidak ada di pasar. Tujuan penimbunan dilakukan dengan sengaja sampai dengan batas waktu untuk menunggu tingginya harga barang-barang tersebut. Muhammad dalam praktek bisnisnya menjauhi tindakan penimbunan. 
barang dagangan Yang dibawa selalu habis. Muhammad sadar bahwa kebutuhan sehari-hari harus didistribusikan dengan baik. Barang dagangan tidak boleh disimpan lama sehingga barang tersebut Langka dijumpai di pasar.

\subsection{Jual Beli Dalam Prespektif Islam 2.3.1 Teori Jual Beli}

Jual beli adalah transaksi antara satu orang dengan orang yang lain yang berupa tukar menukar suatu barang dengan barang yang lain berdasarkan tata cara atau akad tertentu. pada Kenyataannya dalam kehidupan seharihari, Pengertian dari jual beli adalah penukaran barang dengan uang Sedangkan penukaran barang dengan barang tidak lazim disebut jual beli, Melainkan disebut barter. Menurut pengertian fiqih, Jual beli adalah menukar suatu barang dengan barang yang lain dengan rukun dan syarat tertentu.

Terjadinya jual beli karena adanya perbedaan kebutuhan hidup antara satu orang dengan orang lain. suatu contoh misalnya, Salah satu pihak memiliki barang, tetapi membutuhkan uang. Sementara itu, pihak yang lain memiliki uang, Tetapi mereka membutuhkan barang. Kedua belah pihak tersebut dalam contoh diatas, dapat mengadakan kerjasama di antara keduanya dalam bentuk jual-beli atas dasar sama-sama rela. dengan kerja sama jual beli itu, Kebutuhan masing-masing pihak dapat terpenuhi.

Jual beli menurut islam mengajarkan setiap pemeluknya untuk selalu berusaha mencari karunia Allah dengan bermuamalat secara jujur dan benar serta jual beli merupakan Muamalat yang dihalalkan Allah sebagaimana dalam firman Allah subhanahu wa ta'ala:

"Dan tolong menolonglah kamu dalam

(mengerjakan) kebajikan dan takwa dan

janganlah tolong-menolong dalam berbuat dosa

dan pelanggaranpelanggaran" (QS.Al-Maidah:

$5: 2)$

\subsubsection{Hukum Jual Beli}

Hukum Islam dalam masalah dagang belum berlaku secara resmi di Indonesia. Karena rakyat Indonesia mayoritas menganut agama islam, maka bagi mereka harus patuh terhadap ajaran Islam, berusaha melaksanakan syariat Islam dalam kehidupan sehari-harinya seperti dalam kegiatan dagang.Dasar hukum jual beli adalah mubah (boleh). Allah SWT telah menghalalkan praktik jual beli sesuai ketentuan dan syari'at-Nya. Allah SWT berfirman:

"Dan Allah telah menghalalkan jual beli dan mengharamkan riba. (QS. Al-Baqarah: 275).

Dasar hukum jual beli dalam sunnah Rasulullah Saw. terdapat dalam hadits yang berbunyi: 
"Nabi saw. dilanya tentang mata pencaharian yang puling baik. beliau menjawab, seseorang bekeja dengan tangannya dan setiap jual beli yang mabrur." (HR. Ahmad) (Imam Al-Hafidz, 2008).

Dasar hukum jual beli dalam Ijma' menyatakan bahwa ulama sepakat jual beli diperbolehkan dengan alasan bahwa manusia tidak akan mampu mencukupi kebutuhan dirinya sendiri, tanpa bantuan orang lain atau barang milik orang lain yang dibutuhkannya, namun harus diganti dengan barang lain yang sesuai (Rahmad Syafe'i, 2006).

Akan tetapi pada saat situasi tertentu, kondisi atau keadaan berbeda jual beli bisa menjadi wajib dan juga bisa berhukum haram. Jual beli menjadi wajib ketika terjadi praktek ihtikar (penimbunan barang sehingga stok hilang dari pasar dan harga melonjak naik). Menurut pakar Fiqh Maliki pihak pemerintah boleh memaksa pedagang itu menjual barangnya sesuai dengan harga sebelum terjadinya pelonjakan harga. Dalam hal kasus semacam itu, pedagang itu wajib menjual barang miliknya penurunan harga sesuai dengan ketentuan pemerintah. Akan tetapi jual beli bisa menjadi makruh bahkan pada tingkatan haram, misalnya jual beli barang yang tidak bermanfaat, seperti rokok, itu dikatakan sebagai jual beli yang makruh dan ada pula ulama yang mengatakan haram hukumnya. (Syaikh Muhammad, 2009).

Menurut Abdul Wahab Khallaf (1994), Hukum jual-beli itu bisa sesuai dengan situasi dan kondisi yang ada, antara lain :

1. Mubah (boleh), ialah hukum asal jualbeli akan tetapi masih dalam catatan yakni rukun dan syarat jual-beli, barulah dianggap sah menurut syara', seperti jual beli yang biasa dilakukan dipasar, contohnya jual beli sembako.

2. Sunnah, misalnya dalam jual beli barang yang hukum menggunakan barang yang diperjual-belikan itu sunnah seperti minyak wangi.

3. Wajib, misalnya jika pada suatu saat para pedagang menimbun beras, sehingga stok beras di pasar sedikit yang mengakibatkan harganya pun melambung tinggi, maka pemerintah boleh memaksa para pedagang untuk menjual beras yang ditimbunnya.

4. Makruh, jual beli pada waktu datangnya panggilan adzan shalat Jum'at, Dan jual beli yang apabila barang yang diperjual belikan itu hukumnya makruh seperti rokok dan makanan berbau.

5. Haram, apabila tidak memenuhi syarat dan rukun jual beli yang telah ditentukan oleh syara'. Pada ketentuan haram terdapat dua pembagian yakni haram lidatihi dan haram ligairihi. 
6. Sah tapi haram, jual beli ini sebenarnya menurut syara' sah-sah saja, hanya saja tidak diijinkan oleh agama yang menjadi pokok larangannya adalah karena menyakiti penjual atau pembeli atau kepada yang lain, menyempitkan gerakan pasaran dan merusak ketentraman umum menurut Syamsul Rijal Hamid (2003).

\subsection{Prinsip-prinsip Bisnis Islam}

Berikut ini prinsip-prinsip umum ekonomi Islam (Hasan, 2007) :

\subsubsection{Kesadaran Terhadap Isi Alam \\ Maksud dari kesadaran terhadap isi} alam bahwa semua yang ada di muka bumi dan seluruh alam semesta adalah milik Allah dan diciptakan untuk kemashlahatan manusia yang mampu memakmurkan dan mensejahterakan manusia lahir-bathin, jika berlandaskan pada llmu yang berasal dari sang pencipta-Nya sendiri, yaitu ilmu ekonomi Islam, yang mengajarkan bagaimana sebaiknya mengelola isi alam yang diperuntukkan untuk kemakmuran manusia (Hasan, 2007).

\subsubsection{Kekayaan Manusia dan Cara Pengelolaannya}

Setiap fasilitas atau kekayaan yang dimiliki manusia tidak lebih hanya sebagai titipan Allah. Titipan tersebut dapat diperoleh langsung maupun tidak langsung atau melalui usaha dan kerja keras manusia. Kesalahan besar bagi manusia apabila sumber daya tersebut, tidak berhasil mensejahterakan manusia.

Disamping itu harta atau kekayaan yang dimiliki manusia, pada suatu hari akan dipertanggungjawabkan dari mana diperoleh dan kemana dibelanjakan (Hasan, 2007). Allah berfiman:

"Hai arang-orang yang beriman, makanlah diantara rezeki yang baik-baik yang Kami berikan kepadamu dan bersyukurlah kepada Allah, jika benar-benar kepada-Nya kamu menyembah". (QS. Al-Baqarah : 172)

\subsubsection{Menghemat Sumber Daya}

Pada dasarnya ekonomi Islam sangat mengutamakan perilaku hemat, baik dalam konsumsi, maupun didalam proses produksi. Dengan berlaku hemat dalam proses produksi, maka tingkat efisiensi tertentu dapat dicapai dan peluang untuk mendapatkan keuntungan cukup besar. Dengan berlaku hemat dalam bidang konsumsi maka tercapai kepuasan yang optimal. Artinya seorang konsumen hanya akan mencapai kepuasan yang optimal (keseimbangan) jika tidak berlaku boros. Apabila konsumen mencapai posisi keseimbangan berarti secara teoritis konsumen tersebut berada pada jalur yang sesuai dengan tuntunan syariah. Karena syariah menghendaki agar konsumen tidak kikir dan tidak boros. Posisi antara kikir dan boros terletak titik hemat yang membawa posisi optimal bagi konsumen hadits Rasulullah SAW: 
Dari Jabir bin Abdullah radhiyAllahu 'anhuma dia berkata; Rasulullah shallAllahu 'alaihi wasallam bersabda: "Tutuplah tempat air kalian, pintu rumah kalian, dan matikanlah lampu-lampu kalian, karena bisa jadi tikus akan menarik sumbu lampu sehingga mengakibatkan kebakaran yang menimpa para penghuni rumah." (HR. Bukhari).

\subsubsection{Menepati Ketentuan Metrologi}

Satuan perhitungan dalam bisnis adalah panjang, berat, volume, kadar dan sebagainya. Jika sudah terdapat ukuran yang disepakati baik secara umum maupun khusus, para pelaku ekonomi harus mematuhinya. Patuh terhadap yang telah diterima dan telah diketahui oleh masyarakat adalah sesuai dengan tuntunan syariah dan sebaliknya apabila berusaha mendapatkan keuntungan secara tidak halal maka membawa mudharat buat manusia, hanya soal waktu yang akan membuktikan kebenarannya. Allah berfirman:

"Dan sempurnakanlah takaran apabila kamu menakar, dan timbanglah dengan neraca yang benar. Itulah yang lebih utama (bagimu) dan lebih baik akibatnya," (QS. Al-Isra': 35)

\subsubsection{Jujar Dan Transparan}

Salah satu variabel yang menentukan keberhasilan berdagang adalah kejujuan. Sehubungan dangan itu semua, maka manusia patut kiranya mempertahankan nilai-nilai kejujuran dalam berbagai transaksi ekonomi yang dicapai. Kalau ada barang yang diperjual belikan kejujuran harus selalu dikedepankan. Tanpa perilaku jujur bisnis yang dibangun akan berantakan. Kalau ada yang sukses dengan kebohongan, maka kesuksesan itu akan bersifat temporer, karena akan sangat rapuh kelangsungan usaha dalam jangka panjang dengan kata lain, waktulah yang akan membuktikan kapan bangkrutnya sebuah usaha yang dibangun diatas kebohongan (Aedy, 2007). Allah berfirman:

"Hai arang-orang beriman hendaklah kamu jadi orang-orang yang selalu menegakkan kebenaran) karena Allah SWT menjadi saksi dengan adil. Dan janganlah sekali-sekali kebencianmu terhadap suatu kaum mendorong kamu untuk berlaku tidak adil. Berlaku adillah karena adil lebih dekat dengan takwa." (QS, Al-Maidah: 8).

Bagi pedagang, yang harus dilakukan dalam berdagang adalah menjelaskan kepada pembeli atau calon pembeli ketika terjadi kenaikan harga dan wajib membayar zakat atas harta yang telah ia dapatkan jika telah sampai pada haul dan njsabnya.

\subsubsection{Memperlakukan Tenaga Kerja Sebagai Mitra}

Ekonomi Islam menganggap tenaga kerja adalah mitra kerja atau keluarga, bukan sekedar faktor produksi, karena itu kepentingannya menjadi perhatian utama. Dalam hal penetapan upah dan sistem 
pembayarannya telah dilembagakan dalam bentuk yang sangat harmonis, dimana upah dibayar dengan jumlah yang sesuai kesepakatan bersama tampa dengan tekanan apapun, dan pembayarannya tepat waktu. (Hasan, 2007) Dalam hadits juga dikatakan: Dari 'Abdullah bin 'Umar, Rasulullah Saw bersabda:

"Berikan kepada seorang pekereja upahnya

sebelum keringatnya kering." (HR. Ibnu

Majah).

Maksud hadits ini adalah bersegera menunaikan hak si pekerja setelah selesainya pekerjaan atau membayarkan gaji sesuai ketentuan waktu yang telah di sepakati bersama.

\subsubsection{Menghindari Sistem Ribawi}

Menurut Aedy (2011), banyak ekonomi dunia berpendapat kalau pelaku bisnis memperoleh banyak kredit bank dengan sistem ribawi, karena adanya pinjaman bank berarti adanya kepercayaan berarti adanya modal besar untuk melakukan investasi yang dapat membuka lapangan pekerjaan dan meningkatkan pertumbuhan ekunomi, namun Allah membantah semua pendapat tersebut dengan firmanNya yang berbunyi:

"Dan sesuatu riba (tambahan) yang kamu berikan agar dia bertambah pada harta manusia, maka riba itu tidak menambah pada sisi Allah. Dan apa yang kamu berikan berupa zakat yang kamu maksudkan untuk mencapai keridhaan
Allah, maka (yang berbuat demikian) itulah orang-orang yang melipat gandakan pahalanya)," (QS. Ar-Ruum 39)

\section{Metode Penelitian}

3.1 Lokasi, Rancangan Penelitian

Penelitian ini dilakukan di Pasar Sentral Kota Kendari dengan metode wawancara terkait variabel dari prinsip bisnis Islam, dan angket terkait biodata responden. Variabel dari prinsip bisnis Islam yang diukur dan dianalisis antara lain: Mencapai kepuasan dan keuntungan secara halal, menepati ketentuan meterologi, jujur dan transparan, memperlakukan tenaga kerja sebagai mitra, dan menghindari sistem ribawi. Penelitian ini bersifat deskriptifkualitatif yang tujuannya untuk menyajikan gambaran lengkap mengenai suatu fenomena atau kenyataan sosial, dengan jalan mendeskripsikan sejumlah variabel yang berkenaan dengan penelitian.

\subsection{Populasi dan Sampel}

Populasi dalam penelitian ini adalah seluruh groceries stall yang berjualan di dalam Pasar Sentral Kota Kendari. Adapun jumlah groceries stall berdasarkan survey awal peneliti yang dilakukan pada tanggal 24 Maret 2016 di pasar Sentral Kota Kendari yaitu sebanyak 38 groceries stall, Penentuan sampel dilakukan secara sensus yaitu mengambil seluruh populasi menjadi sampel 
penelitian, yang biasa disebut sampel jenuh (Riduwan, 2016). Dengan demikian jumlah sampel sebanyak 38 responden, namun berdasarkan hasil wawancara, hanya 21 dari responden yang bersedia untuk diwawancarai. Sehingga responden yang akan dianalisis berdasarkan hasil wawancara adalah 21 responden.

\subsection{Teknik Pengumpulan Data,} Sumber Data dan Analisis Data

Teknik pengambilan data menggunakan metode Angket (biodata), Interview (wawancara) dan Observasi (pengamatan), Sumber data dalam penelitian ini menggunakan data primer dan sekunder selanjutnya dianalisis secara kualitatif agar diperoleh suatu gambaran dan jawaban yang jelas mengenai pokok permasalahan.

Metode yang digunakan dalam penelitian ini adalah crosstab (tabulasi silang). Menurut Santoso dan Tjiptono (2001), mengatakan bahwa penelitian crosstab (tabulasi silang) menyajikan data dalam bentuk tabulasi yang meliputi baris dan kolom.

Penerapan prinsip bisnis Islam berdasarkan variabel dan indikator dapat diketahui dengan melihat seberapa besar persentase yang diperoleh dari penerapan prinsip tersebut, kemudian untuk mengetahui persentase keseluruhan dari tiap variabel, maka dapat dihitung melalui persentase yang dirumuskan sebagai berikut:

Persentase rata-rata penerapan variabel penelitian perindikator:

Rumus : Jumlah keseluhan presentase indikator dari satu variabel / Banyaknya indikator variabel tersebut

\subsection{Variabel dan Definisi Operasional} Variabel

Untuk menghindari pemahaman yang berbeda-beda, maka penulis melakukan operasionalisasi variabel sebagai berikut:

1. Bisnis Islam adalah suatu kegiatan bisnis yang pada hakekatnya tidak semata-mata bersifat material (mencari keuntungan duniawi), telapi juga bersifat inmaterial (mencari keuntungan akhirat) dimana dilakukan dengan cara profesional dan juga harus sesuai dengan syariat Islam.

2. Prinsip-prinsip bisnis Islam yang akan diteliti yakni : Mencapai kepuasan dan keuntungan secara halal, jujur dan transparan, memperlakukan tenaga kerja sebagai mitra, dan menghindari system ribawi.

3. Prinsip mencapai kepuasan dan keuntungan secara halal yang dimaksud adalah para groceries stall dalam prakteknya tidak menipu, mengontrol expire sembako, tidak menjual barang yang sudah rusak atau tidak layak. 
4. Prinsip jujur dan transparan yang dimaksud adalah para groceries stall menyatakan sesuatu (kondisi barang) dengan sesungguhnya dan apa adanya, tidak di tambahi ataupun tidak dikurangi.

5. Prinsip memperlakukan tenaga kerja sebagai mitra yang dimaksud adalah para groceries stall memperlakukan karyawannya sebagai teman, bukan sebagai bawahan serta membayar upah karyawan tepat waktu.

6. Prinsip menghindari sistem ribawi dan perdagangan uang yang dimaksud dalah para groceries stall dalam berbisnis tidak menggunakan modal dari lembaga keuangan yang memiliki sistem riba.

7. Groceries stall adalah pelaku usaha yg melakukan aktifitas bisnis yang dijadikan sebagai sampel dalam penelitian.

\section{Hasil dan Pembahasan}

4.1 Karekteristik Responden

\subsubsection{Karakteristik Responden \\ Berdasarkan Pengalaman \\ Berdagang \\ Pengalaman berdagan merupakan} landasan awal memahami perkembangan usaha dari masa kemasa sehinga mengetahui selukbeluk untuk mengembangkan usaha.
Tabel 1. Jumlah Responden Berdasarkan Pengalaman Berdagang

\begin{tabular}{|c|c|c|c|}
\hline No. & $\begin{array}{c}\text { Lama } \\
\text { Berdagang } \\
\text { (Tahun) }\end{array}$ & Jumlah(Org) & $\begin{array}{c}\text { Presentase } \\
\mathbf{( \% )}\end{array}$ \\
\hline 1 & Dibawahl0 & 14 & 66,66 \\
\hline 2 & $11-20$ & 5 & 23,80 \\
\hline 3 & $21-30$ & 2 & 9,52 \\
\hline \multicolumn{2}{r|}{ Total } & 21 & 100,00 \\
\hline
\end{tabular}

Sumber: Diolah (Lampiran)2019

Dari 21 responden terbanyak adalah 14 orang atau 67\% merupakan pedagang yang lama berdagangnya adalah dibawah 10 tahun. Hal ini dapat di interpretasikan bahwa sebagian besar groceries stall di Pasar Sentral Kota Kendari mempunyai pengalaman yang cukup dalam berdagang.

\subsubsection{Berdasarkan Aktifitas Keagamaan}

Kepatuhan menjalankan ibadah merupakan salah satu indicator dalam menilai seorang groceries stall berprilaku sesuai sunnah Rasullah dalam berniaga.

\section{Tabel 2. Jumlah Responden Berdasarkan Ketaatan Beribadah (Shalat 5 Waktu) dan Mengikuti Pengajian}

\begin{tabular}{|c|c|c|c|}
\hline No. & $\begin{array}{c}\text { Menjalankan } \\
\text { Shalat 5 } \\
\text { Waktu }\end{array}$ & $\begin{array}{c}\text { Jumlah } \\
\text { (Orang) }\end{array}$ & $\begin{array}{c}\text { Presentase } \\
\mathbf{( \% )}\end{array}$ \\
\hline 1 & Selalu & 17 & 80,95 \\
\hline 2 & $\begin{array}{c}\text { Kadang- } \\
\text { Kadang }\end{array}$ & 3 & 14,28 \\
\hline 3 & Jarang & - & - \\
\hline 4 & Tidak & 1 & $5,76 \mathrm{~s}$ \\
\hline \multicolumn{2}{r|}{ Total } & $2 \mathrm{l}$ & 100,00 \\
\hline
\end{tabular}

Sumber: Diolah (Lampiran) 2019

Berdasarkan 21 orang yang diambil, sebagai responden terbanyak adalah I7 orang atau $81 \%$ merupakan pedagang yang selalu menjalankan shalat lima waktu dan mengikuti pengajian. Hal ini dapat di interpretasikan bahwa sebagian besar 
groceries stall di Pasar Sentral Kota Kendari taat dalam beribadah.

\subsection{Hasil Penelitian}

4.2.1 Mencapai Kepuasan dan Keuntungan Secara Halal

Seorang pedagang dalarn kegiatan

bisnisnya tidak boleh melakukan penipuan dan harus selalu berusaha untuk mendapatkan keuntungan yang halal dengan cara memberikan pelayanan terbaik kepada pembeli, diantaranya adalah selalu menyeleksi barang yang akan dijual, mengontrol expire sembako, tidak menjual barang yang sudah rusak atau tidak layak dan tidak mencampur barang berkualitas bagus dengan yang berkualitas biasa/buruk.

\subsubsection{Mengontrol Kadaluarsa Sembako}

Tabel 3. Rekapitulasi Pengontrolan Kadaluarsa Sembako

\begin{tabular}{|c|c|c|c|}
\hline $\begin{array}{c}\text { No } \\
\cdot\end{array}$ & $\begin{array}{c}\text { Menyeleksi } \\
\text { Barang } \\
\text { Tidak Layak } \\
\text { Jual }\end{array}$ & $\begin{array}{c}\text { Jumlah } \\
(\text { Orang } \\
\text { ) }\end{array}$ & $\begin{array}{c}\text { Presentas } \\
\text { e (\%) }\end{array}$ \\
\hline 1 & Ya & $2 l$ & 100,00 \\
\hline 2 & Tidak & - & - \\
\hline \multicolumn{2}{|c|}{ Total } & $2 l$ & 100,00 \\
\hline
\end{tabular}

Sumber: Diolah (Lampiran)2019

Dari 21 responden secara keseluruhan menyatakan selalu mengontrol expire sembako. Hal ini dapat di interpretasikan bahwa seluruh groceries stall yang berjualan di Pasar Sentral Kota Kendari sudah mencapai keuntungan secara halal. Artinya, keuntungan yang diperoleh didapatkan dari hasil penjualan produk yang tidak kadaluwarsa.
4.2.2 Tidak Mencampur Barang Yang Berkualitas Bagus Dengan Yang Berkualitas Biasa/buruk

Pada indikator ini, peneliti melakukan penelitian dengan cara mewawancarai beberapa responden yang dianggap dapat menjadi informan kunci dan salah satunya mengatakan pernyataan yang mewakili beberapa responden dengan jawaban sama sebagai berikut : "Saya mempunyai pelanggan dari suatu pulau, setiap pelanggan itu berbelanja, dia hanya menitipkan sebuah catatan melalui $A B K$ kapal, seperti biasa saya menyiapkan barang-barang belanjaannya dan langsung mengirimkannya melalui kapal tersebut. Ternyata ada satu belanjaannya yang kurang, karena pada saat itu stok beras habis. Agar tidak mengecewakan pelanggan, dan barangnya harus dikirim tepat waktu, maka saya mengambil beras dari pedagang $A$ dan langsung mengirimnya. Seminggu kemudian seperti biasa seorang ABK kapal membawakan catatan dari pelanggan saya tersebut. Setelah saya melihat catatannya, terdapat tulisan berhuruf besar dengan huruf kapital "TOLONG KALAU MENGIRIM BERAS PILIHKAN YANG BAGUS-BAGUS". Setelah membaca catatan tersebut saya jadi heran, perasaan beras itu bagus, disitulah saya menduga kalau berasnya itu telah dicampur. Sejak saat itu, jika stok beras saya habis saya tidak lagi mengambil beras ke pedagang $A$. Selama ini, saya sudah pernah mengambil beras ke 
pedagang B,C,D dan E. Alhamdulillah tidak pernah lagi ada komplain dari pelanggan saya."

Berdasarkan pernyataan tersebut, dapat diketahui bahwa dari 5 pedagaug sembako yang menjadi sampel, terdapat 1 pedagang yang melakukan kecurangan. Dalam hal ini penulis dapat menyimpulkan bahwa sebanyak $80 \%$ atau 4 orang tidak mencampur barang yang berkualitas bagus dengan yang berkualitas biasa/buruk, dan $20 \%$ atau 1 orang melakukan kecurangan dengm mencampur barang yang berkualitas bagus dengan yang berkualitas biasa/buruk. Hal ini dapat diinterpretasikan bahwa masih terdapat adanya pemalsuan barang yang dilakukan oleh groceries stall dalam hal mencampur barang yang berkualitas bagus dengan yang berkualitas biasa/buruk, walaupun sebagian besar dari groceries stall di Pasar Sentral Kota Kendari tidak melakukan hal tersebut.

\subsubsection{Jujur dan Transparan}

$\begin{array}{lll}\text { 4.2.3.1 } & \text { Menjelaskan } & \text { Kepada } \\ & \text { pembeli/konsumen } & \text { Ketika } \\ & \text { Terjadi Kenaikan Harga } & \end{array}$

Tabel 4. Rekapitulasi Menjelaskan Kenaikan Harga Barang

\begin{tabular}{|c|c|c|c|}
\hline No. & $\begin{array}{c}\text { Menjelaskan } \\
\text { Kenaikan } \\
\text { Harga Barang }\end{array}$ & $\begin{array}{l}\text { Jumlah } \\
\text { (Orang) }\end{array}$ & $\begin{array}{c}\text { Persentase } \\
(\%)\end{array}$ \\
\hline 1 & Selalu & 15 & 71,42 \\
\hline 2 & Kadang & 5 & 23,80 \\
\hline 3 & Jarang & 1 & 4,76 \\
\hline \multicolumn{2}{|r|}{ Total } & 21 & 100,00 \\
\hline
\end{tabular}

Sumber: Diolah (Lampiran)

Dapat dijelaskan bahwa sebagian besar responden selalu menjelaskan kepada konsumen/pembeli jika terjadi kenaikan harga barang dengan persentase tertinggi yaitu $71 \%$ atau 15 orang pedagang dan sisanya sebanyak $28 \%$ jarang meberitahukan kepada konsumen.

\subsubsection{Membayar Zakat}

Tabel 5. Rekapitulasi Pembayaran Zakat Harta

\begin{tabular}{|c|c|c|c|}
\hline No. & $\begin{array}{c}\text { Membayar } \\
\text { Zakat Harta }\end{array}$ & $\begin{array}{c}\text { Jumlah } \\
\text { (Orang } \\
\text { ) }\end{array}$ & $\begin{array}{c}\text { Persentas } \\
\text { e (\%) }\end{array}$ \\
\hline 1 & Selalu & 19 & 90,47 \\
\hline 2 & Kadang & 1 & 4,76 \\
\hline 3 & Jarang & 1 & 4,76 \\
\hline \multicolumn{2}{|c|}{ Total } & 21 & 100,00 \\
\hline
\end{tabular}

Sumber: Diolah (Lampiran) 2019

Dari 21 responden groceries stall bahwa rata-rata responden selalu membayar zakat harta dengan persentase tertinggi yaitu $90 \%$ atau 19 orang pedagang sehingga dapat diinterpretasikan bahwa sebagian besar groceries stall di Pasar Sentral Kota Kendari selalu membayar zakat harta.

Tabel 6. Rekapitulasi Pengetahuan Responden Terhadap Haul dan Nisab Zakat Harta

\begin{tabular}{|c|c|c|c|}
\hline $\begin{array}{c}\text { No } \\
\cdot\end{array}$ & $\begin{array}{c}\text { Tingkat } \\
\text { Pengetahua } \\
\mathbf{n}\end{array}$ & $\begin{array}{c}\text { Jumlah } \\
\text { (Orang } \\
\text { ) }\end{array}$ & $\begin{array}{c}\text { Persentas } \\
\text { e (\%) }\end{array}$ \\
\hline 1 & Tahu & 10 & 47,61 \\
\hline 2 & Tidak Tahu & 11 & 52,38 \\
\hline \multicolumn{2}{|c|}{ Total } & 21 & 100,00 \\
\hline
\end{tabular}

Sumber:Diolah (Lampiran) 2019

Dapat dijelaskan bahwa sebagian besar responden tidak mengetahui haul dan nisab zakat harta dengan persentase (52\%) atau 11 orang pedagang. Hal ini dapat di interpretasikan bahwa sebagian besar responden tidak mengetahui haul dan nisab zakat harta namun, memahami 
bahwa setiap harta yang didapatkan harus ada yang di keluarkan(zakat).

\subsubsection{Memperlakukan Tenaga Kerja Sebagai Mitra}

Tabel 7. Rekapitulasi Responden Yang Memililki Karyawan

\begin{tabular}{|c|c|c|c|}
\hline No. & Karyawan & $\begin{array}{c}\text { Jumlah } \\
\text { (Orang) }\end{array}$ & $\begin{array}{c}\text { Persentase } \\
(\mathbf{\%})\end{array}$ \\
\hline 1 & Ada & 17 & 80,95 \\
\hline 2 & Tidak ada & 4 & 19,04 \\
\hline \multicolumn{2}{|c|}{ Total } & 21 & 100,00 \\
\hline
\end{tabular}

Sumber: Diolah (Lampiran) 2019

Tabel diatas menunjukan bahwa hanya (19\%) atau 4 orang responden yang memiliki karyawan, selebihnya tidak menggunakan karyawan dalam berdagang dengan persentase $(81 \%)$ atau 17 orang responden. Hal ini dipicu oleh kegiatan pedagang yang rata-rata tidak memiliki kegiatan lain selain berjualan sembako.

a) Membayar upah sesuai kesepakatan

Untuk indikator ini, peneliti mengklasifikasikan jam kerja karyawan dan seberapa besar upah yang diberikan. Adapun klasifikasinya adalah sebagai betikut:

Tabel 8. Klasifikasi Memperlakukan

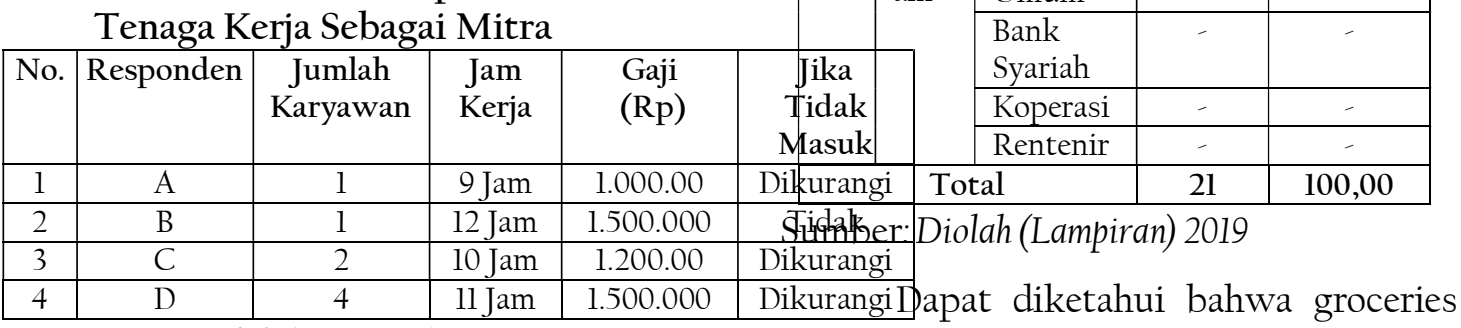
Sumber: Diolah (Lampiran) 2019

Berdasarkan tabel 8 disimpulkan bahwa mereka telah membayar upah sesuai dengan hasil keringat karyawannya sesuai dan kesepakatan bila tidak masuk kerja akan dikurangi tetapi ada pula yang tidak di kurangi dgn persentase terkecil. Hal ini disebabkan oleh karena karyawan tersebut adalah kerabat dekat dari responden.

b) Memberlakukan Karyawan Seperti Keluarga

Berdasarkan hasil observasi peneliti, keempat responden tersebut memberlakukan karyawannya dengan sangat baik, selalu bercanda dengan karyawan dan tidak memerintah secara kasar, bahkan salah satu responden menyatakan bahwa sesekali ia memberikan makan siang kepada karyawannya. Hal ini dapat diinterpretasikan bahwa seluruh responden yang memiliki karyawan sudah memberlakukan karyawan seperti keluarga.

\subsubsection{Menghindari Sistem Ribawi} 4.2.5.1 Sumber Dana Usaha

\section{Tabel 9. Rekepitulasi Sumber Dana}

\section{Usaha}

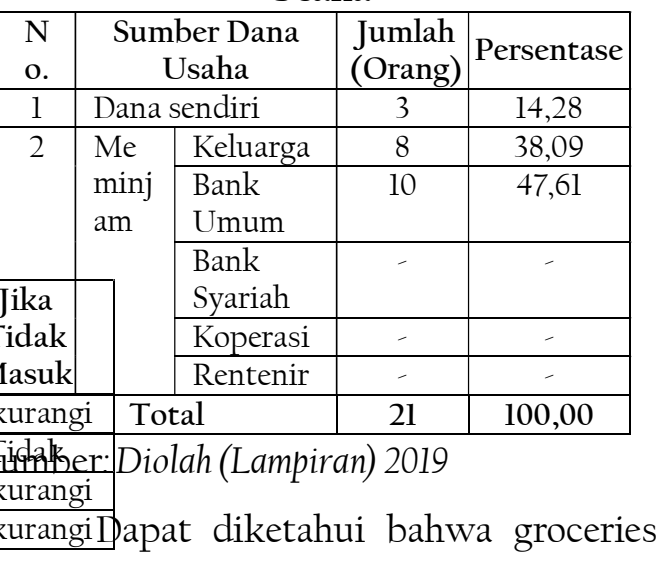

stall dalam menjalankan dana usaha mempunyai sumber dana paling besar berasal dari pinjaman Bank Umum melalui Kredit Usaha Rakyat (KUR) kemudian pinjaman kepada keluarga dan dana sendiri. Alasan pedagang tidak meminjam 
di Bank Syariah karena kurangnya pengetahuan atau informasi mengenai produk Bank Syariah.

\subsubsection{Pengetahuan Responden} Terhadap Bank Syariah

Tabel 10. Klasifikasi Pengetahuan Responden Terhadap Bank Syariah

\begin{tabular}{|c|c|c|c|}
\hline $\begin{array}{c}\text { No } \\
\cdot\end{array}$ & $\begin{array}{c}\text { Bank Syariah } \\
\text { Halal }\end{array}$ & $\begin{array}{c}\text { Jumlah } \\
\text { (Orang) }\end{array}$ & $\begin{array}{c}\text { Persentase } \\
\text { (\%) }\end{array}$ \\
\hline 1 & Tahu & 4 & 19,04 \\
\hline 2 & Tidak Tahu & 17 & 80,95 \\
\hline \multicolumn{2}{r|}{ Total } & 21 & 100,00 \\
\hline
\end{tabular}

Sumber: Diolah (Lampiran) 2019

Berdasarkan Tabel diatas diketahui

bahwa sebagian besar responden tidak mengetahui seluk beluk Bank Syariah dengan persentase $81 \%$ atau 17 orang responden. Sehingga tidak dapat dielakkan masih banyaknya pedagang yang menganut sistem ribawi dalam menjalankan bisnisnya, terbukti dari cukup tingginya tingkat penggunaan pinjaman ke Bank Umum.

Setelah melihat beberapa paparan hasil di atas, dapal dilihat penerapan prinsip bisnis Islam melalui hasil rekapitulasi bérdasarkan masing-masing variabel pada Tabel berikut:

Tabel 11. Rekapitulasi Penerapan Prinsip Bisnis Islam Berdasarkan Variabel/Indikator

\begin{tabular}{|c|c|c|c|c|}
\hline No & Variabel & Indikator & Rekapitulasi & Rata-rata \\
\hline \multirow[t]{3}{*}{1} & \multirow{3}{*}{$\begin{array}{l}\text { Mencapai } \\
\text { kepuasan dan } \\
\text { keuntungan } \\
\text { secara halal }\end{array}$} & Mengontrol expire sembako & 100,00 & \multirow{3}{*}{84,00} \\
\hline & & $\begin{array}{l}\text { Tidak mencampur barang } \\
\text { berkualitas dengan berkualitas } \\
\text { biasa/buruk }\end{array}$ & 80,00 & \\
\hline & & $\begin{array}{l}\text { Menjelaskan ketika terjadi } \\
\text { kenaikan harga }\end{array}$ & 71,00 & \\
\hline \multirow[t]{2}{*}{2} & \multirow[t]{2}{*}{$\begin{array}{l}\text { Jujur dan } \\
\text { transparan }\end{array}$} & $\begin{array}{l}\text { Menjelaskan Kenaikan Harga } \\
\text { Barang }\end{array}$ & 71,00 & \multirow[t]{2}{*}{80,50} \\
\hline & & Membayar zakat harta & 90,00 & \\
\hline \multirow[t]{2}{*}{3} & \multirow{2}{*}{$\begin{array}{l}\text { Memperlakuk } \\
\text { an tanaga } \\
\text { kerja sebagai } \\
\text { mitra }\end{array}$} & $\begin{array}{lll}\text { Membayar } & \text { Upah } & \text { Sesuai } \\
\text { Kesepakatan } & & \end{array}$ & 100,00 & \multirow{2}{*}{100,00} \\
\hline & & $\begin{array}{l}\text { Memberlakukan karyawan seperti } \\
\text { keluarga }\end{array}$ & 52,00 & \\
\hline \multirow[t]{2}{*}{4} & \multirow{2}{*}{$\begin{array}{l}\text { Menghindari } \\
\text { sistem ribawi }\end{array}$} & Sumber Dana Usaha & 85,00 & \multirow[t]{2}{*}{83,00} \\
\hline & & $\begin{array}{l}\text { Pengetahuan Responden Terhadap } \\
\text { Bank Syariah }\end{array}$ & 80,95 & \\
\hline
\end{tabular}

Sumber: Diolah (Lampiran) 2019

\subsection{Pembahasan}

Berdasarkan hasil penelitian yang dilakukan oleh peneliti, dapat lihat bahwa groceries stall di Pasar Sentral Kota Kendari sudah menerapkan prinsip bisnis Islam dalam menjalankan usahanya, namun belum sempurna dalam penerapannya. Hal tersebut dapat dilihat dari uraian pembahasan berikut :
4.3.1 Mencapai Kepuasan dan Keuntungan Secara Halal
Seorang pedagang memiliki hak dalam menentukan cara apapun yang ia gunakan dalam berdagang dan barang apa 
saja yang akan ia jual, karna Islam tidak membatasi hal itu. Namun, pedagang muslim seyogyanya menjalankan usaha mereka dengan cara yang halal agar mendapatkan berkah dan ridha dari Allah, baik di dunia maupun di

akhirat. Hal ini sejalan dengan penjelasan Samdin, dkk (2013) bahwa setiap kegiatan ekonomi tidak boleh mencampur adukan antara kebaikan dan keburukan, sesuatu yang telah dianggap baik (halal) menurut syariat akan tetap baik untuk dilakukan dan sebaliknya sesuatu yang telah dianggap buruk (haram), juga akan tetap tidak diperbolehkan. Sebagaimana firman Allah :

"Hai orang-orang yang beriman, janganlah kamu saling memakan harta sesamamu dengan jalan yang batil, kecuali dengan jalan perniagaan yang berlaku dengan suka sama-suka di antara kamu. Dan janganlah kamu membunuh dirimu; sesungguhnya Allah adalah Maha Penyayang kepadamu" (QS. An-Nisa: 29)

Hasil dari penelitian ini, menujukkan bahwa hampir seluruh responden groceries stall di Pasar Sentral Kota Kendari telah menerapkan variabel mencapai kepuasan dan keuntungan secara halal.

\subsubsection{Mengontrol Expire Sembako} Seluruh Responden di Pasar Sentral Kota Kendari selalu menerapkan indikator ini. Hal ini menunjukkan bahwa tingginya kesadaran pedagang terhadap kualitas barang yang akan dijual. Pengontrolan expire sembako sangat diperlakukan oleh pedagang, untuk menghindari adanya sembako yang mungkin kurang baik untuk dikonsumsi. Berkaitan dengan prinsip sejalan dengan konsep Norsyam (2013) yang menjelaskan bahwa barang yang diperjual belikan harus diteliti lebih dulu.

\subsubsection{Tidak Mencampur Barang Berkualitas Bagus Dengan Yang Berkualitas Biasa/Buruk.}

Mencampur barang yang berkualitas hagus dangan yang berkualitas biasa/buruk adalah perkara tidak halalnya suatu perdagangan. Pada indikator ini, peneliti mengumpulkan data dengan cara mewawancarai informan kunci, yaitu pedagang yang dianggap dapat mewakili seluruh pedagang di Pasar Sentral Kota Kendari. Dari hasil penelitian, terbukti bahwa masih terdapat pedagang yang mencampur barang yang berkualitas bagus dengan barang yang berkualitas biasa/buruk, walaupun sebagian besar groceries stall tidak melakukan hal tersebut. Penelitian ini sejalan dengan penelitian Mukarrom (2014) yang menyatakan bahwa oknum pemasok beras membedakan kualitas beras yang akan dijual. Hal ini sesuai dengan hadits Nabi: 
"Rasul bertanya, "Wahai lelaki apa ini?" Perjual itu mengatakan, "Lembab dari langit" maksudnya, terkena hujan. Rasul bersabda, "Kenapa tidak engkau letakkan di atas sisanya (yang kering) agar orang lain melihat? Siapa yang menipu dalam muamalah, maka ia tidak termasuk darigolonganku." (HR. Muslim)

\subsubsection{Jujur dan Transparan} Indikator dari variabel ini adalah menjelaskan ketika terjadi kenaikan harga dan membayar zakat. Alasan responden menerapkan prinsip ini adalah karena responden menganggap bahwa kejujuran sangat diperlukan dalam setiap perkatan maupun perbuatan, begitu pula dalam berdagang, dengan jujur seorang pedagang akan mendapatkan kepercayaan dan akan berujung pada kesuksesan. Hal ini sejalan dengan penjelasan Aedy (2007) bahwa tanpa perilaku jujur bisnis yang dibangun akan berantakan. Kalau ada yang sukses dengan kebohongan, maka kesuksesan itu akan bersifat temporer, karena akan sangat rapuh kelangsungan usaha dalam jangka panjang. Sebagaimana dalam hadist:

"Pedagang yang jujur serta terpercaya (tempatnya) bersama para Nabi, orang-orang yang jujur, dan orang-orangyang mati syahid pada hari kiamat". (HR. Bukhari, Hakim,

Tirmidzi dan Ibnu Majjah)
4.3.4.1 Menjelaskan Ketika Terjadi
Kenaikan Harga

Pedagang yang jujur adalah pedagang yang selalu menjelaskan apa adanya jika ditanyakan oleh pembeli, terutama ketika terjadi kenaikan harga, Pada indikator ini, hampir seluruh responden menjelaskan apa adanya jika ditanya oleh pembeli

\subsubsection{Membayar Zakat}

Zakat merupakan hukum Islam yang ke empat. Mengeluarkan zakat harta hukumnya wajib jika telah mencapai nishab dan haulnya.

Sebagaimana dalam firman Allah:

"Dan dirikanlah shalat tunaikanlah zakat

dan ruku'lah beserta orang-orang yang

ruku'.“(QS. Al-Baqarah 143)

Kejujuran seorang pedagang dapat dilihat jika saalah satunya ialah rutin membayar zakat. Kewajiban membayar zakat telah diketahui oleh seluruh responden, dan sebagian besar responden telah melaksanakannya Namun, banyak dari responden yang belum mengetahui haul dan nishab zakat yang harus dikeluarkan hartanya. $\mathrm{Hal}$ ini sesuai dengan pemaparan Mahfud (2011) yang menyatakan bahwa harta yang dikeluarkan zakatnya akan menjadi berkah, tumbuh, berkembang dan bertambah, suci dan beres (baik).

\subsubsection{Memperlakukan Tenaga Kerja Sebagai Mitra \\ Tenaga kerja bukan sekedar faktor produksi, tenaga kerja juga manusia biasa}


yang harus diperlakukan sebaik mungkin. Seorang pedagang yang memiliki karyawan, hendaknya memperhatikan kepentingan karyawannya, membayar upah sesuai dengan hasil keringatnya tepat waktu dan memperlakukan karyawan seperti keluarga. Pada hasil penelitinn, seluruh responden yang memiliki karyawan telah menerapkan prinsip ini.

\subsubsection{Membayar Upah Sesuai Dengan} Kesepakatan

Berkaitan dangan indikator membayar upah yang sesuai, Rasulullah menegaskan bahwa seorang pedagang harus memberikan gaji/upah karyawannya tepat waktu melalui sabdanya :

Dari 'Abdullah bin 'Umar, Rasulullah

Saw bersabda "Berikan kepada seorang

pekerja upahnya sebelum/keringatnya kering." (HR. Ibnu Majah).

Pada indikator ini, tidak terdapat responden yang mempekerjakan karyawan dengan semena-mena. Gaji karyawan diberikan sesuai dengan jam kerja mereka. Hal ini dapat dikatakan bahwa seluruh responden yang memiliki karyawan telah memenuhi hak karyawannya dengan membayar upah mereka sesuai dengan kesepakatan dan hasil kerja mereka. Hal ini sejalan dengan hadits yang berbunyi:

"Barang siapa yang saudaranya berada di bawah perintahnya (bekerja untuknya), maka berikan makanan yang sama dengan yang ia makan, pakaian yang ia kenakan, dan hendaknya tidak memberikan tugas diluar batas kewajaran yang lantas dapat menyebabkan sakit" (HR. Bukhari).

\subsubsection{Menghindari Sistem Ribawi} Seorang pedagang hendaknya menjalankan usaha yang tidak mengandung unsur riba, baik itu sebagai pelaku atau ikut serta di dalamnya. Karena sudah Jelas di dalam Al-Qur'an Surah AlBaqarah ayat 275 bahwa riba adalah suatu perkara yang diharamkan oleh Allah. dan terdapat juga dalam surah $\mathrm{Al}$-Baqarah ayat 278 mengenai larangan riba Allah berfirman:

"Hai arang-orangyang beriman, tinggalkanlah sisa-sisa riba jika kamu beriman" (QS. Al-Baqarah: 278)

Terkait prinsip menghindari riba, peneliti melihat dari sisi sumber pendanaan usaha responden. Dalam hal ini, responden terbanyak adalah responden yang mendapatkan sumber dana dari Bank Umum dengan persentase 48\%. Hal ini tidak dapat dipungkiri, melihat dari kurangnya pemahaman responden terhadap riba itu sendiri dan tentang halalnya Bank Syariah

\section{Kesimpulan dan Saran}

5.1 Kesimpulan

1. Groceries stall di Pasar Sentrar Kota Kendari telah menerapkan prinsipprinsip bisnis Islam dalam berdagang, 
namun masih terdapat beberapa pedagang yang semata-mata mencari keuntungan yang besar tanpa memperdulikan syariat Islam dalam berdagang. Adapun prinsip-prinsip berdagang yang diterapkan dalam Islam yakni: Mencapai kepuasan dan keuntungan secara halal, Jujur dan transparan, Memperlakukan tenaga kerja sebagai mitra dan Menghindari sistem ribawi. Diterapkannya prinsipprinsip bisnis ini merupakan wujud dari kesadaran para pedagang bahwa segala kekayaan yang dimiliki adalah titipan dari Allah.

2. Variabel yang rendah penerapannya adalah pemanfaatan bank syariah, dimana semua groceries stall, tidak ada yang menggunakan bank syariah, bahkan hampir separuh dari groceries stall masih menggunakan bank konvensional dalam menjalankan usahanya. Hal ini menjelaskan implikasi bahwa pengetahuan pedagang terhadap keutamaan bank syariah masih kurang.

3. Pada prinsip kejujuran dalam ruang lingkup zakat menyarakan bahwa seluruh groceries stall telah menerapkannya, namun banyak dari pedagang yang belum mengetahui seluk beluk mengenai perhitungan zakat yang sebenamya.

\subsection{Saran}

1. Berdasarkan pembahasan hasil penelitian dan kesimpulan, maka perlu adanya upaya-upaya perbaikan yang dapat dilihat dari saran-saran sederhana berikut :

2. Groceries stall seharusnya dapat mempertahankan prinsip bisnis Islam yang sudah diterapkan dalam menjalankan bisnisnya, walaupun dalam prosesnya masih menyisakan jual beli yang dilarang dalam Islam.

3. Groceries stall seharusnya lebih memperluas pengetahuan keislaman, khususnya dalam hal jual beli, baik tentang zakat maupun riba, agar dapat mengaplikasikan perdagangan yang sesuai dengan syariat Islam.

4. Bagi dinas terkait (Dinas Perindag, Balai POM, Kepolisian, dan Pengelola Pasar Sentral Kota Kendari) diharapkan lebih aktif dalam melakukan pengawasan terhadap proses jual beli sembako yang dapat menimbulkan peluang terjadinya kecurangan yang merugikan konsumen. 


\section{Daftar Pustaka}

Aedy Hasan, 2007. Indahnya Ekonomi Islam. Bandung, Alfabeta.

2011. Teori dan Aplikasi Etika Bisnis Islam. Bandung, Alfabeta.

Akib Nurusshabriyah, 2015. Studi Penererapan Etika Biknis Islam Pada Pelaku Bisnis Muslim Di Kota Kendari, Skripsi, Universitas Halu Oleo, Kendari.

Al-Qur'an dan Al-Hadits.

Hamid Syamsul Rijal, 2003. Buku Pintar Agama Islam, Jakarta Timur, Penebar Salam.

Hidayatullah Haris, t.t. Etika Bisnis Dalam Perspektif AI-Qur'an: Upaya Membangun Bisnis Yang Islami Untuk Menghadapi Tantangan Bisnis Di Masa Depan (Jurnal). Fakultas Agama Islam, Unipdu Jombang.

Mahfud Rois, 2011. Al-Islam Pendidikan Agama Islam. Jakarta, Erlangga.

Maulana Amhar, 2013. The Definition of Islamic Business and type of Business Organisation in An Islamic Economics, Pengertian Bisnis Dalam Islam, Artikel.

Norsyam.M, 2013. Jual beli Menurut Syariah, Makalah, http://moh.norsyam.blogspot.co.id. Diakses 6 Mei 2016.

Riduwan, 2016. Belajar Mudah Penelitian untuk Guru-Karayawan dan Peneilti Pemula Bandung, Alfabeta.

Saifullah Muhammad, 2003, Etika Bisnis Islami Dalam Praktek Bisnis Rasulullah, Jumal, IAIN Walisongo Semarang.

Samdin dkk, 2013. Mengelola Bisnis Syariah Konsep Dasar dan Implementasi Kendari. Unhalu Press.

Syafe'i Rahmad, 2006. Fiqh Muamalah. Bandung, Pustaka Setia.

Wahab Khallaf Abdul, 1994. Kaidahkaidah Hukum Islam. Jakarta, Raja Grafindo Pesada. 